\title{
The genome of the brown alga Ectocarpus siliculosus contains a series of viral DNA pieces, suggesting an ancient association with large dsDNA viruses

\author{
Nicolas Delaroque* and Wilhelm Boland
}

\author{
Address: Max-Planck-Institut für Chemische Ökologie, Beutenberg Campus, Hans Knöll Str. 8, D - 07745 Jena, Germany \\ Email: Nicolas Delaroque* - ndelaroque@ice.mpg.de; Wilhelm Boland - boland@ice.mpg.de \\ * Corresponding author
}

Published: 12 April 2008

BMC Evolutionary Biology 2008, 8:1 I0 doi:10.1 I86/147|-2|48-8-110

This article is available from: http://www.biomedcentral.com/I47I-2/48/8/II0

(c) 2008 Delaroque and Boland; licensee BioMed Central Ltd.

This is an Open Access article distributed under the terms of the Creative Commons Attribution License (http://creativecommons.org/licenses/by/2.0), which permits unrestricted use, distribution, and reproduction in any medium, provided the original work is properly cited.

\begin{abstract}
Background: Ectocarpus siliculosus virus-I (EsV-I) is a lysogenic dsDNA virus belonging to the super family of nucleocytoplasmic large DNA viruses (NCLDV) that infect Ectocarpus siliculosus, a marine filamentous brown alga. Previous studies indicated that the viral genome is integrated into the host DNA. In order to find the integration sites of the viral genome, a genomic library from EsV-I-infected algae was screened using labelled EsV-I DNA. Several fragments were isolated and some of them were sequenced and analyzed in detail.
\end{abstract}

Results: Analysis revealed that the algal genome is split by a copy of viral sequences that have a high identity to EsV-I DNA sequences. These fragments are interspersed with DNA repeats, pseudogenes and genes coding for products involved in DNA replication, integration and transposition. Some of these gene products are not encoded by EsV-I but are present in the genome of other members of the NCLDV family. Further analysis suggests that the Ectocarpus algal genome contains traces of the integration of a large dsDNA viral genome; this genome could be the ancestor of the extant NCLDV genomes. Furthermore, several lines of evidence indicate that the EsV-I genome might have originated in these viral DNA pieces, implying the existence of a complex integration and recombination system. A protein similar to a new class of tyrosine recombinases might be a key enzyme of this system.

Conclusion: Our results support the hypothesis that some dsDNA viruses are monophyletic and evolved principally through genome reduction. Moreover, we hypothesize that phaeoviruses have probably developed an original replication system.

\section{Background}

For several years, the investigation of novel dsDNA viruses has excited the imagination of virologists and evolutionists, prompting the development of several original theories about the evolution of certain dsDNA viruses and their role in shaping the genome of the organisms of the tree of life. It has been proposed that dsDNA viruses were the evolutionary origin of the eukaryotic nucleus or at least that they have contributed to its creation by transferring genetic information to the nucleus [1-7].

The recent discovery and characterization of several large dsDNA viruses from aquatic environments belonging to the phycodnavirus and mimivirus families led to the 
development of new hypotheses [8-10]. A comparative analysis of the gene content of these viruses with poxviruses, iridoviruses and asfarviruses indicated that they have nine gene products in common, and 33 more gene products are present in at least two of these families. It follows that they might have a common evolutionary ancestor, a nucleocytoplasmic large dsDNA virus (NCLDV) $[11,12]$. Although most evolutionists seem to accept the hypothesis of a common ancestor, there is no consensus concerning the general morphology of the ancestral NCLDV and how it evolved to give rise to the different classes of viruses. On the one hand, the ancestral NCLDV is believed to have been a dsDNA virus which has evolved by acquiring genes from the host and bacterial endosymbionts and gene duplication [13]. On the other hand, the ancestral NCLDV could have been a huge virus or even a cellular organism that evolved through genome regression [9,14-16].

A well-studied NCLDV is Ectocarpus siliculosus virus-1 (EsV-1), a phaeovirus that infects a small marine filamentous alga, Ectocarpus siliculosus. Phaeoviruses belong to the Phycodnavirus family. They possess icosahedral morphologies with internal lipid membranes and large doublestranded DNA genomes [17]. EsV-1 and other phaeoviruses only infect free-swimming, wall-less gametes or spores. One copy of the DNA is integrated into the cellular genome and then transmitted via mitosis through all cell generations of the developing host [18-20]. The viral genome remains latent in vegetative cells and is expressed in cells of the reproductive algal organs, sporangia and gametangia only when stimulated by, for example, changes in light composition and temperature $[17,21]$. Infected algae show no apparent growth or developmental defects other than partial or total inhibition of reproduction and phaeoviruses are pandemic in several brown algal species examined [17]. In addition to its lysogenic life cycle, the genome structure is the major feature which distinguishes EsV-1 from other NCLDVs. The genome is circular, but sequencing the genome resulted in a linear molecule of 335,593 bp ending in inverted repeats. Such a molecule might be able to assemble and form a circular genome [22,23]. It also contains numerous singlestranded regions randomly distributed over the genome whose functions remain unknown [24].

Another characteristic of the genome is its low gene density compared to other NCLDV genomes. The 231 genes occupy only $70 \%$ of EsV-1 genome; these were assembled in islands of densely packed genes that are separated by large regions of DNA repeats and noncoding sequences [23]. In fact, the EsV-1 genome resembles a small eukaryotic chromosome more than a typical viral genome. A comparative analysis of the EsV-1 genome with the genome of two other phycodnaviruses indicated that they could have evolved by loss of genes from a common ancestor, possibly an endosymbiotic organism, thereby supporting the theory of genome regression [25].

To elucidate how the EsV-1 genome is replicated, we first tried to determine where the viral genome is integrated into the host genome. We screened a cosmid library of Ectocarpus algae infected by EsV-1 using labelled EsV-1 DNA as a probe. Sequencing and analysis showed that the host chromosomal DNA was interspersed with single copies of small fragments of viral DNA. However, the fragments diverged in their DNA sequence from the corresponding EsV-1 DNA sequences. In the vicinity of these segments, we found other viral genes and pseudogenes, some of which are present only in the genome of the mimivirus. This finding indicates that the Ectocarpus genome contains remnants of the genome of either one giant dsDNA virus or one unicellular organism; this organism could be the ancestor of the contemporary NCLDVs.

Furthermore, this hypothesis is supported by previous data, indicating that the viral integrated fragments might be reassembled to constitute the EsV-1 genome. A putative protein coded by the EsV-1 and algal genome might be a key enzyme of this mechanism due to its similarity to tyrosine recombinases.

\section{Results}

To determine where the viral genome is integrated in the host chromosome, we screened a genomic library of Ectocarpus siliculosus sporophyte NZVicZ14 infected by EsV-1. The strain NZVicZ14 was created by mating a male gamete from the strain NZ88 $15 \mathrm{~d} 2 \mathrm{~m}$ containing the EsV-1 genome with a non-infected female gamete from the strain Vic88 12-15 f [26]. The DNA used for constructing the NZVicZ14 library was isolated from filaments prior to the appearance of symptoms and EsV-1 virions in order to limit the number of positive clones containing viral DNA from EsV-1 particles. The library was screened with radiolabeled EsV-1-DNA that had been digested with the DNA restriction enzyme Sau3A. The screening isolated 200 positive clones whose cloned fragments have an average size of $35 \mathrm{~kb}$. To distinguish clones containing EsV-1 DNA linked to algal DNA from clones containing only EsV-1 DNA, the isolated positive clones were screened with labelled algal DNA from Vic88 12-15 f female gametophytes.

Surprisingly, all the clones were positive, indicating that they also have algal DNA. Consequently, no clone possessing only EsV-1 DNA was isolated. This result may be due either to the absence of viral particles in the algae or to the single-stranded DNA regions of the EsV-1 genome: these regions make the viral DNA fragile and therefore 
might render large DNA fragments of EsV-1 in the cosmid vector unclonable [22].

The terminal regions of the EsV-1 genome are thought to be recognized by a putative protelomerase coded by the EsV-1 genome which could in turn linearize the EsV-1 genome and form telomeres [27]. So far, however, experiments to investigate this possibility have not succeeded. To investigate the hypothesis that the terminal repeats might also be the sequences involved in the integration of the viral DNA into the host genome, a second screen was performed using the probes A and A' corresponding to the terminal regions of the viral genome (Fig. 1). Of the 200 positive clones previously isolated, only four overlapping clones hybridized to both probes. Therefore, other clones have viral DNA that is not related to the terminal region. The DNA fragments of the positive clones can be assembled to form a 51-kb genomic region; such a region has been almost entirely sequenced and analyzed (Table 1 and Fig. 1, region A). The genomic region contains a ca. 5430 bp fragment that is $98 \%$ identical to a segment overlapping the terminal region of the EsV-1 genome (Table 1, Fig. 1). The region of identity of the viral fragment and the EsV-1 genome is located just upstream of the promoter region of ORF 1 and ends approximately in the middle of ORF 231 (Fig. 1). The protein product of ORF 231 has no counterpart in the protein data banks [23]. Moreover, a recent blast search of the region indicated that ORF 231 is probably not a gene, since pieces of another ORF situated in ORF 231 code for remnants of a transposase which is related to those coded by the EsV-1 genome (Fig. 1) [23].

The integrated viral fragment contains the same DNA inverted repeats in the same orientation as that which characterizes the EsV-1 genome. Moreover, region A contains additional similar repeats at one extremity (Fig. 1). Apparently, the terminal DNA repeats of EsV-1 genome are longer than previously reported [23] (unpublished results). The discrepancy in the DNA sequence between the proviral and EsV-1 DNA sequences is due to small mutations, deletions or insertions, indicating that the integrated fragments have either accumulated mutations during the evolution or come from an Ectocarpus virus other than EsV-1.

Several genes and remnants of genes were found in the vicinity of the viral fragments. Two homologues of ORF 213 of EsV-1 are present in tandem, upstream of ORF 1 (213h1 and 213h2, Fig. 1). ORF 213 is capable of encoding a large enzyme; this enzyme might be involved in DNA integration and recombination (Fig. 2). Protein 213 possesses at its C-terminus a tyrosine-recombinase domain resembling those found in the members of the integrase family whose hallmark is an invariant pattern of four amino acids (Arg, His, Arg, Tyr) forming the catalytic site [28]. ORF 213h1 and 213h2 do not have any similarity in their DNA sequences with ORF 213, indicating that ORF $213 \mathrm{~h} 1$ and $213 \mathrm{~h} 2$ are either algal genes or viral genes that NZVic14 horizontally acquired from another virus. The second copy of the gene is truncated at its $\mathrm{C}$ terminus resulting in the absence of a part of the tyrosine recombinase domain (Fig. 1 and 2). A homologue of ORF 213 was also found in the genome of another phaeovirus, the Feldmannia irregularis virus (FirrV-1), signifying that protein 213 might be essential for the life cycle of the phaeoviruses [25].

A putative transposase, Tn1, which shares identity with eukaryotic transposases of the Fot 1 family, is also present. It is predicted to contain a putative intron with $5^{\prime}-\mathrm{AG} /$ GUGAGG and 3'UGCAG/GU splice site sequences as well as a branch point UCAC. The genes of EsV-1 genome do not contain introns, whereas these are common in the algal genes. This therefore supports the contention that region $\mathrm{A}$ is composed of viral DNA framed by algal DNA.

In order to know whether other clones contain viral DNA, several DNA inserts were partially sequenced and analyzed. Viral DNA identical to EsV-1 DNA was missing. Of these sequenced inserts, one contains viral DNA at one extremity (Table 1; Fig. 1, region B). This clone, which has been sequenced to completion and analyzed, contains two fragments which have 88 and $94 \%$ identity to EsV-1 DNA (Fig. 1 and Table 2). The fragments possess pseudoand homologues of ORF 20, 22 and 23 from EsV-1 (Fig.

Table I: Comparison of the viral integrated fragments of regions A, B, C vs the EsV-I genome.

\begin{tabular}{|c|c|c|c|c|c|}
\hline $\begin{array}{l}\text { Ectocarpus genomic } \\
\text { region }\end{array}$ & $\begin{array}{c}\mathrm{G}+\mathrm{C} \text { of the genomic } \\
\text { region }(\%)\end{array}$ & $\begin{array}{l}\text { Position of the viral } \\
\text { integrated fragments }\end{array}$ & $\begin{array}{l}\mathrm{G}+\mathrm{C} \text { of the viral } \\
\text { fragments }(\%)\end{array}$ & $\begin{array}{l}\text { Position of the similar fragment } \\
\text { in the EsV- I genome }\end{array}$ & Identity \\
\hline \multirow[t]{3}{*}{$A$} & 52.30 & & & & \\
\hline & & $7036-894 I$ & 48.22 & $332959-3720$ & $543|/ 54| 4$ (98\%) \\
\hline & & $11748-15413$ & 50.8 & & \\
\hline \multirow[t]{3}{*}{ B } & 51.3 & & & & \\
\hline & & $7-934$ & 52.5 & $37542-38469$ & $833 / 938(88 \%)$ \\
\hline & & $6586-9708$ & 51.5 & $40867-43989$ & $2978 / 3153(94 \%)$ \\
\hline \multirow[t]{2}{*}{ C } & 53.3 & & & & \\
\hline & & $25376-26459$ & 51.75 & $190061-188934$ & $989 / 1144$ (86\%) \\
\hline
\end{tabular}




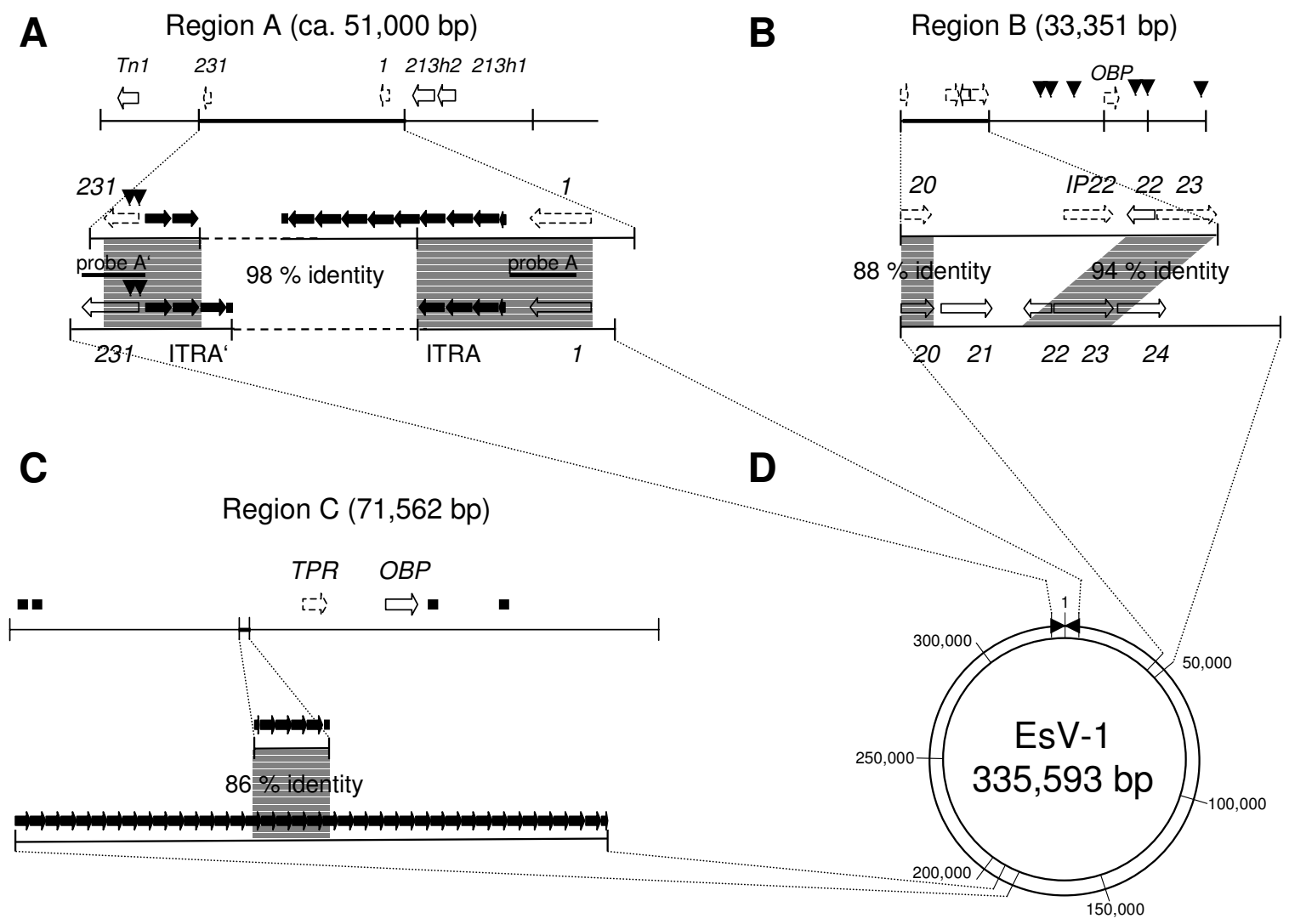

\section{Figure I}

Genetic organization and comparative genomic analysis of three Ectocarpus algal genomic regions. A, B, and C, maps of the algal genomic and portions of the EsV-I genome. Gray regions connect homologous genomic regions. Dashed line, unknown DNA sequence. Arrow, putative ORF; broken arrow, pseudo-gene; black arrow, DNA repeats; black square, remnant of ankyrin repeats; arrowhead, relic of transposase; Tn, transposase; numbers indicate ORFs or homologues of the EsV-I genome; $2 \mathrm{I} 3 \mathrm{hl}$ and $2 \mathrm{I} 3 \mathrm{~h} 2$, homologues of EsV-I ORF 2I3; OBP, origin binding protein; IP22, Isoleucine/leucine proline repeat; TPR, tetratricopeptide-repeat. D, Circular map of the EsV-I genome. Triangles, the inverted terminal repeats, ITRA and ITRA'. Numbers, nucleotide coordinates.

1). They are arranged as in the EsV-1 genome but diverge at the DNA level. Moreover, region $\mathrm{B}$ has a pseudogene whose translated product contains FNIP repeats. The pseudogene is situated between ORF 20 and ORF 22 instead of ORF 21 (Fig. 1). Interestingly, the EsV-1 genome does not contain FNIP repeats; in contrast, the mimivirus genome codes for at least 8 proteins containing this class of repeat $[9,29]$. Remarkably, the region contains another pseudogene coding for an origin binding protein (OBP); this OBP has its best identity with the MIMIR1 protein, one of the two putative OBPs of the giant mimivirus (Fig. 3 and Table 2). Although the identity is low, the UL-9 helicase domain with its ATP-binding site and DEAD site is still recognizable (Fig. 3). The OBP is also coded by the genome of the Herpes virus and Asfarvirus but is absent in the EsV-1 genome. OBP protein plays a major role in the replication of viral DNA [30]. In addition, region $\mathrm{B}$ contains relics of transposase as does region $\mathrm{A}$ (Fig. $1 \mathrm{~B})$.

The presence of an OBP-like gene immediately raises the question whether other mimiviral-like genes are present elsewhere in the NZVicV14 Ectocarpus genome. Other DNA inserts were sequenced and analyzed. A genomic region of $70 \mathrm{~kb}$ was assembled with fragments of positive clones (region C, Fig. 1C). Region C contains a small viral DNA insert having a few repeats that are almost identical to those present in region $\mathrm{D}$ of the EsV-1 genome (Fig. 1 and Table 1). Surprisingly, it also has a complete ORF, which is capable of encoding a large OBP. This putative OBP shares identity with MIMIR8, the second and largest OBP coded by the genome of the mimivirus (Fig. 3). Like its MIMIR8 and herpes viral counterparts, this OBP is made of the N-terminal domain of the archaeo-eukaryotic 


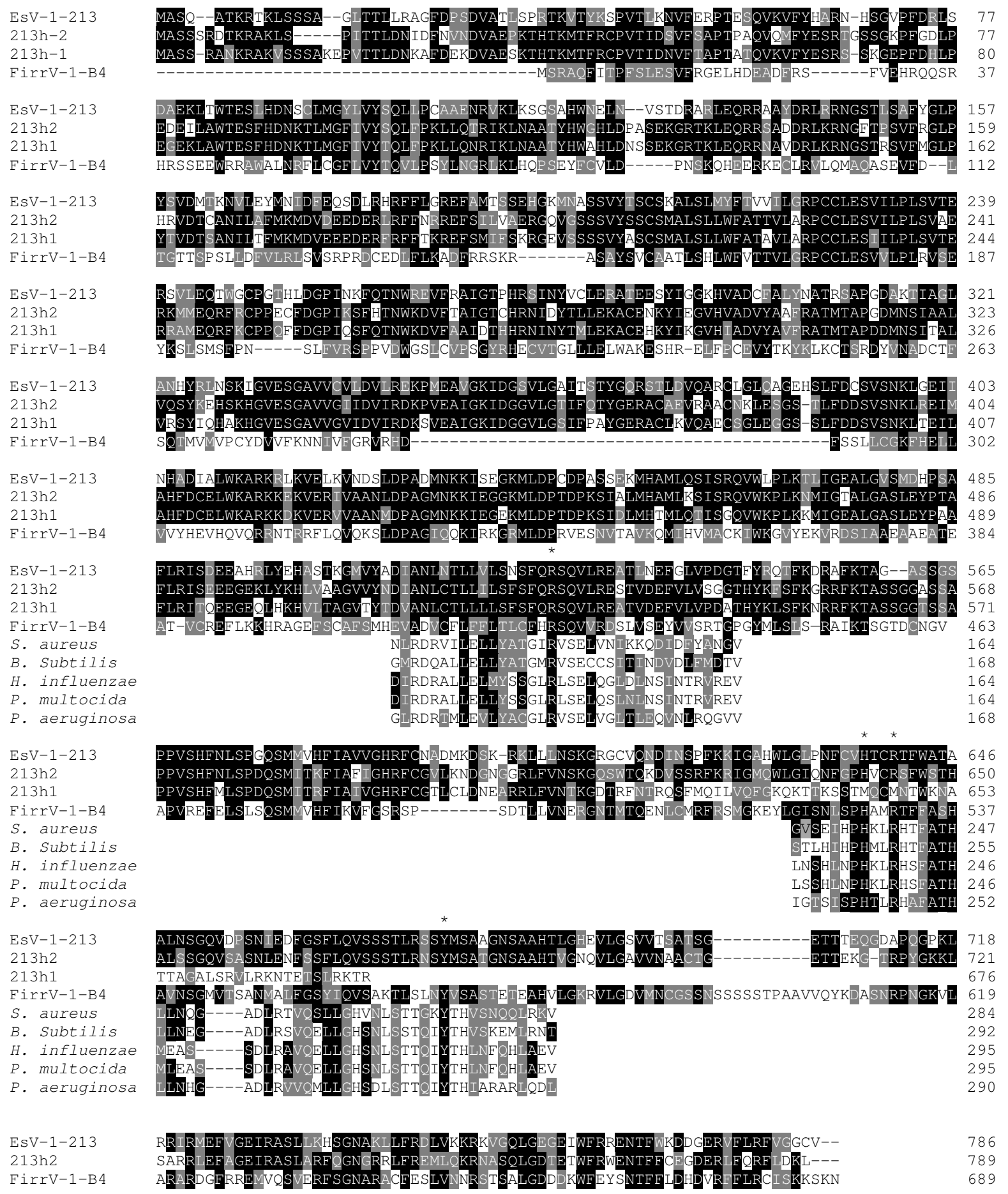

Figure 2

Alignment of the putative viral integrases of Ectocarpus $(2|3 \mathrm{~h}|$ and $2 \mid 3 \mathrm{~h} 2)$, EsV-I and FirrV-I with segments of tyrosine recombinases from various bacteria. Accession numbers: AAKI4627 (EsV-I), AAR26879 (FirrV-I), Q9KJF6 (Staphylococcus aureus), NP 389496 (Bacillus subtilis str. 168), P44818 (Haemophilus influenzae), AAK03785 (Pasteurella multocida str. Pm70) and Q9HXQ6 (Pseudomonas aeruginosa). Asteriks indicate the four invariant amino acids of the tyrosine recombinase domain (Arg, His, Arg, Tyr). 
Table 2: Putative and incomplete ORFs in the three Ectocarpus genomic regions.

\begin{tabular}{|c|c|c|c|c|c|c|c|}
\hline ORF & $\mathrm{G}+\mathrm{C}$ content & Position & Size (aa) & Blast (E value) & Amino acid identity & $\begin{array}{l}\text { Homolog(s) [accession } \\
\text { number] }]^{\mathrm{a}}\end{array}$ & $\begin{array}{l}\text { Putative fonction/Features/ } \\
\text { comments }^{\mathrm{b}}\end{array}$ \\
\hline \multirow[t]{2}{*}{$2|3 \mathrm{~h}|$} & 54.24 & $21498-1947 \mid$ & 675 & 0.0 & $350 / 615(56 \%)$ & $\begin{array}{l}\text { EsV-I-2I } 3 \text { (length } 786 \\
\text { a) [AAKI4627] }\end{array}$ & $\begin{array}{l}\text { Truncated homologue of } \\
\text { EsV-I-2I3 }\end{array}$ \\
\hline & & & & $2 e-35$ & $|38 / 55|(25 \%)$ & $\begin{array}{l}\text { FirrV-I-B4 (length } 689 \\
\text { aa) [AAR26879] }\end{array}$ & \\
\hline \multirow[t]{4}{*}{$213 \mathrm{~h} 2$} & 54.46 & $|80467-| 568 \mid$ & 788 & 0.0 & $443 / 787(56 \%)$ & $\begin{array}{l}\text { EsV-I-2I3 (length } 786 \\
\text { aa) [AAKI4627] }\end{array}$ & $\begin{array}{l}\text { Integrase Phage integrase } \\
\text { family (aa } 490-690) \\
\text { [PF00589] }\end{array}$ \\
\hline & & & & le-73 & $213 / 770$ (27\%) & $\begin{array}{l}\text { FirrV-I-B4 (length } 689 \\
\text { aa) [AAR26879] }\end{array}$ & \\
\hline & & & & 0.43 & $27 / 98$ (27\%) & $\begin{array}{l}\text { Bacillus subtilis site- } \\
\text { specific integrase/ } \\
\text { recombinase B4 (length } \\
304 \text { aa) [NP 389496] }\end{array}$ & \\
\hline & & & & 0.95 & $38 / 85$ (45\%) & $\begin{array}{l}\text { Staphylococcus aureus } \\
\text { subsp. MRSA252 putative } \\
\text { integrase/recombinase } \\
\text { (length 298 aa) } \\
\text { [YP 040639] }\end{array}$ & \\
\hline \multirow[t]{2}{*}{ Tnl } & 56.95 & $6788-4524$ & 541 & le-32 & $132 / 524$ (25\%) & $\begin{array}{l}\text { Aspergillus nidulans FGSC } \\
\text { A4 putative transposase } \\
\text { (length } 554 \text { aa) } \\
\text { [EAA60308] }\end{array}$ & $\begin{array}{l}\text { Transposase helix-turn- } \\
\text { helix, Psq domain (aa I- } \\
\text { 51) [PF05225] [PS50960], }\end{array}$ \\
\hline & & & & $7 e-32$ & I I 0/384 (28\%) & $\begin{array}{l}\text { Aspergillus awamori } \\
\text { transposase (length } 555 \\
\text { aa) [AAC49623] }\end{array}$ & $\begin{array}{l}\text { DDE superfamily } \\
\text { endonuclease (aa I60- } \\
\text { 372) [PF03 I84] Contains a } \\
\text { putative intron (bp } 515 \text { - } \\
\text { II54) }\end{array}$ \\
\hline $22 \mathrm{hl}$ & 54.68 & $7793-6684$ & 369 & $1 e-139$ & $250 / 289(86 \%)$ & $\begin{array}{l}\text { EsV-I-22 [NP 077507] } \\
\text { (length } 284 \text { aa) }\end{array}$ & \\
\hline \multirow[t]{2}{*}{ OBP } & 47.12 & $41598-45086$ & 1162 & $6 e-11$ & $160 / 730(21 \%)$ & $\begin{array}{l}\text { Acanthamoeba polyphaga } \\
\text { Mimivirus helicase, } \\
\text { similar to origin binding } \\
\text { protein (length } 1052 \text { aa) } \\
\text { [YP |42362] }\end{array}$ & $\begin{array}{l}\text { Origin binding protein } \\
\text { AAA (aa 386-562) } \\
\text { [SM00382] [PF00004], } \\
\text { Herpes_ori_bp (aa 40I - } \\
\text { 930) [PF02399], }\end{array}$ \\
\hline & & & & $2 \mathrm{e}-07$ & $65 / 275$ (23\%) & $\begin{array}{l}\text { Acanthamoeba polyphaga } \\
\text { Mimivirus helicase, } \\
\text { similar to origin binding } \\
\text { protein (length } 795 \mathrm{aa} \text { ) } \\
\text { [YP |42355] }\end{array}$ & $\begin{array}{l}\text { ATP/GTP-binding site } \\
\text { motif A (P-loop) (aa } 394- \\
401) \text { [PS000I7], Helicase } \\
\text { domain (aa 38I - 720) } \\
\text { [SM00490] [PFO027I] } \\
\text { [PS5II 92] [PS5II94]. }\end{array}$ \\
\hline
\end{tabular}

a Accession numbers are from the GenBank database.

b Pfam, prosite or Smart codes are in brackets.

primase (AEP) fused to the UL-9-like helicase domain containing an ATP-binding site and DEAD box [31]. However, the Zinc domain present in MIMIR8 is absent in Ectocarpus OBP. No additional ORF of viral origin was found except vestiges of genes coding for tetratricopeptiderepeats (TPR) and ankyrins (Fig. 1). Both kinds of repeats are the most frequent motif detected in putative ORFs of the mimivirus, while ankyrin-repeats were detected only in the EsV-1 genome $[9,23]$. Current sequencing of other clones indicates that the Ectocarpus genome contains several other genes of EsV-1 that could be assembled to form an apparently complete viral genome.
The variation in GC content in chromosomes is a good indicator of recent transposition and integration occurrences. The GC content, which is close to $52 \%$ for the three genomic regions and the integrated viral fragments, shows no traces of a recent integration event (Table 1). Moreover, the GC content of the genomic regions is identical to that of the EsV-1 genome, which is much more than the $28 \%$ GC content of the mimivirus [23,9]. In addition, the GC content of the OBP-like gene of the region $\mathrm{C}$ is $47 \%$, whereas it is only $28 \%$ for the mimiviral gene (Table 2) [9]. Other reported ORFs have a similar GC content close to $52 \%$ (Table 2). Taken together, these data suggest that the integration event of an EsV-like virus must have occurred a long time ago. 
A

ATP-binding site
SFAHVREKVISASATMGSGKTYI

EsV

MIMIR1

EsV

IREFI

LKQFPQGTRVLFVTCE
LDHYDNIKKILWISHE

RVGMAKS I S LIFP--EYSVYLDKN----NQDWQIQEYEFM
RQTLSKOIYGSEKNHGFVNYMDQKGNLFEHDRIIIQIDSL

202

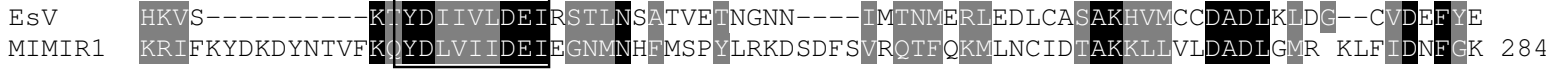

$\begin{array}{ll}\text { EsV } & \text { LVFKGYKIHHIEHIGGDPELHHIFATDERFYERMMSDLEHLKIMVCCGSSKELKAIKEKALSILPEEEVGIYYADSPNQGE } \\ \text { MIMIRI } & \text { SIVVNNNYKPIQKI-----FEITNDLSSEOEILIADIKDGKNVCVVSMSASYLDKLEREAGL--YVIHTSKSDKLKNE } 358\end{array}$

ESV IVNVSEHWKKYRIIGFTSTITVSVSYDG-PIDRVYVAP--CRTSCGPREMNQMVSRARKILSGEVIVKYTG-----------

MIMIR1 LENVNYFWKKFQICCFSPTIECGVDENEKHEDKIYCYLKNGSKICSQRSLLMVGRIRQLGNNKILCYYSGPTNIDADIYTY 440

ESV

MIMIR1

-DAINLYP INMNIN---AFKNMEMNI IMAR-R SAMKSIESNYDKEFYHTIFRIG--AGHYAKFFPSVIT-------HVWVW
DDILGYRHYEKINGRKVLENVEKKEIANGE VTLKRVSANISLFDHIHYNEVEESNKNHSMFITVLFKLIQRAGHSMIF 521

ESV ARVEEHLKLS-----YWYNHY IWILREKKYRF-DLAVDGWKPSLG-TEDDGMSLFLKEETKTVKERMLKMMDVVDVSRMTRR

MIMIR1 NTVEEPEEVEPDNNVISHAEILSMINETKYKISDLMKKOSKNOL RTEKLVLEKYFFMKNFGVKDSNKDEFVKFHKKYANK 603

$\begin{array}{ll}\text { ESV } & \text { EYNFLITKKIKGLASE----EEVVKINKFKVOKFYDFNVNGLFVAEFTK } 507 \\ \text { MIMIR1 } & \text { EITEKHFKRFFGYDNPNNSIDELKHLDIFVSNKKP PNNNNNNELDEHND } 652\end{array}$

B

EsV DEHLILWS-----EDHRETKGEYKISFHVVGGSRLFRGIVTNGPMARLAAEVNTISEKIFEDYPDISSSPREQREMSVLDMG 194 MIMIR8 YDQVIKLSDVLLLNSSGQSSDGYKISVHVVVSPKNKTFYYTNSKKIENNTAYHLYASLININSEYKDKENFNDKP HGYLDEQ 198

EsV VYTKNRSMRGPKASKGVGSQGELPCAGSEGGDLEDF ICKDIPMDDYRDYDFVPNTIKES--KQQRAIAVDKIQTRKVAPTT 274 MIMIR8 VYRKDATLRMIGSCKYPTGDRCLDP IDSKTLEKLDLTDKQKLNYLILYIDDTKPIILLETPIIQQTTISKTKIQHNEPTKTN 280

EsV AQSDLESQIECYLRATQNTDTIKVVFNGLYGAQLLP SYRVDGSGRSCHVCDKVHGRNGAFVKELPTKALLYTCMSSMRSEIL 356 MIMIR8 INNKLLDLVKKYHPSAKQYGSSKEGYYNFNYDNRTEKCPLSGVTHDSNGFYVIEKSSGCFLKCYSKKCHGKSMHLGYVDETD 362 EsV PIFGRVLKTAKVLDTINPEDGRVPDIRTIKDKCINIIAGMNTGKTYRANQLVEALGETLAAKTRVDDPGKSMPPRKLRVLIV 438 MIMIR8 QFVDEAHQINTKYLLQDPLVPKLLEDWINKGKTFAIKSAMGTGKTY----LIKHILDKYKLNKVLWITHRQTLTKSLYGSFK 440 ESV IGETLAAKTRVDDPGKSMPPRKLRVLIVTCRVSMASGLDFRFKGFDQYTDIIDSDRLIIEYESTHR--TDRI YDIIIIDEVR 490 MIMIR8 ILDKYKLNKVLWITHRQTLTKSLYGSEKDYGEVSYMDTQNCLYQYDKVLVQIDSLMRIKEFDMEENKQLVKIY YDLVI IDEIE 494 EsV SVITSATTYATNRSLARN--MERLKKNMDHAOKVILSDADSDLDGAVQYF I HNNFDR----YTEIRLEKPVMRRKMLME- 565 MIMIR8 GCLSHYESPYLNKPDIDSRY I ENF MIDVIRF SNKI IVIDADISIRIQLE IEHIDKITNKGGNYIMINNSYQP ITKTETITND 576 ESV KNKTETTMLDDIRNGRHIVAASFGSRTHMEAVEKLIHLELGSDIKIRTYTGQSPHKKELKNIEKFWPEYQVIMYTSCVTVALD 647 MIMIR8 EGDFDTKLFADIKAKKNICVVSMSAGAVNKIAVELN-KMGIKYVSHTSKSNDS LKKNLEDVNNEWKQQQVVMF SPSIISGID 657 ESV YNNVVHR---VFAFPKTTTMSPREMLQSIGRSRNVLTN-------EVVVSVDNNEKLEGRLHP---NFDMDYIYKEQLKLIM 716 MIMIR8 FNEIHFDKMYCIIKSGNKTCDPRSFLQMVGRIRHLGDONIFCWYQQIP IFIDKTNKIIPKLQSDVYIFDDLLSYYRYYETLR 739 EsV EKRTTLEMMEETVDEDGRIKWWVN--HITKLWAYNLAETSLKYGHWYAHFLWILEKKQLECVHEVHDGGCKKNYDEILKEFT 796 MIMIR8 NKKIIKNVVYETVEGDDVISEVNKSVEIDLEDKISLHNEVEQLNKHQDVEITVLNR------LIMRAGNKIDEKLVLKDDK 814

ESV FESEQEEIATFNEIDVSCNDHGWYLNALENQRAGVSCRY IMQLRKYKVQRFFMDSLHGKDIIFYEKHHRQIWNQLAVTKLA 878

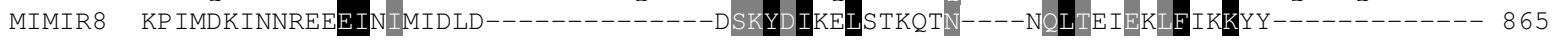

ESV REEMANLWRKDLKIDKDFAKDDYKVLPLLEDVLKHMGFSGFADRSSKVDVRGLPENKKAMEILEOITAITMNTRNRAEEPIN 960 MIMIR8 -- --- FKKKLGIKKEIDKDK-----LRELMTKYMDKEYEIER----------YEILFGYKKISDSNDDSKTKEKDRIK 923

EsV R-VKSYLESITGITLSNQKKQIRGDRFRQYFITDKPG IQYILELNH IMMTDSWIODKRESLNPKRIPGREQTMITDRWIES 1040

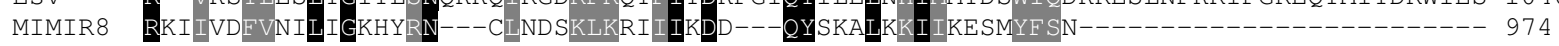

ESV KKEEERAHVLEKEREEKRENERQRERNTKNISSRVLRIVVQTRILCIIVQTRKDYCGVFYLYYL 1104 MIMIR8 ---EEKYRPLFRKKKGSLKSNPKKEKEIQFYISTLVRLIREYNIILKVESRKKTNGKSSYLRSL 1035

Figure 3

Alignment of segments of Ectocarpus OBPs with the mimiviral counterparts. A, OBP of region $B$ with MIMIRI (YP_142355). B; OBP of region C with MIMIR8 (YP_142362). The putative ATP binding site and DEAD region of helicases' superfamily are boxed. 


\section{Discussion}

Ectocarpus' genome illustrates the evolution of NCLDVs In this study, we showed that the genome of Ectocarpus siliculosus contains proviral fragments that share a high identity with regions of the genome of the EsV-1 and mimivirus. However, the integrated sequences are more similar in structure, gene organization and GC content and at the DNA and protein level to the EsV-1 genome than to the mimiviral genome.

The genome of Feldmannia, another filamentous brown alga which is not able to produce virions, also contains viral fragments [32]. In contrast to Ectocarpus, viral DNA sequences similar to mimiviral sequences have so far not been detected in the genome of Feldmannia algae.
Therefore, the presence of the viral sequences in the genome of Feldmannia and Ectocarpus raises the question of their origin. In the case of Ectocarpus, because screening isolated the one copy of the viral sequences, the most obvious explanation is that these viral sequences are remnants of one ancient viral infection. We believe that these integrated sequences represent traces of an ancestral NCLDV that could be either a giant virus or an even more complex organism (Fig. 4A). The occurrence of DNA sequences similar to mimiviral sequences among the EsV1-like fragments indicates that these sequences might come from an organism having a large genome. Such an organism was probably at least as big as the mimivirus and may even have possessed the gene content of EsV-1 and mimivirus.

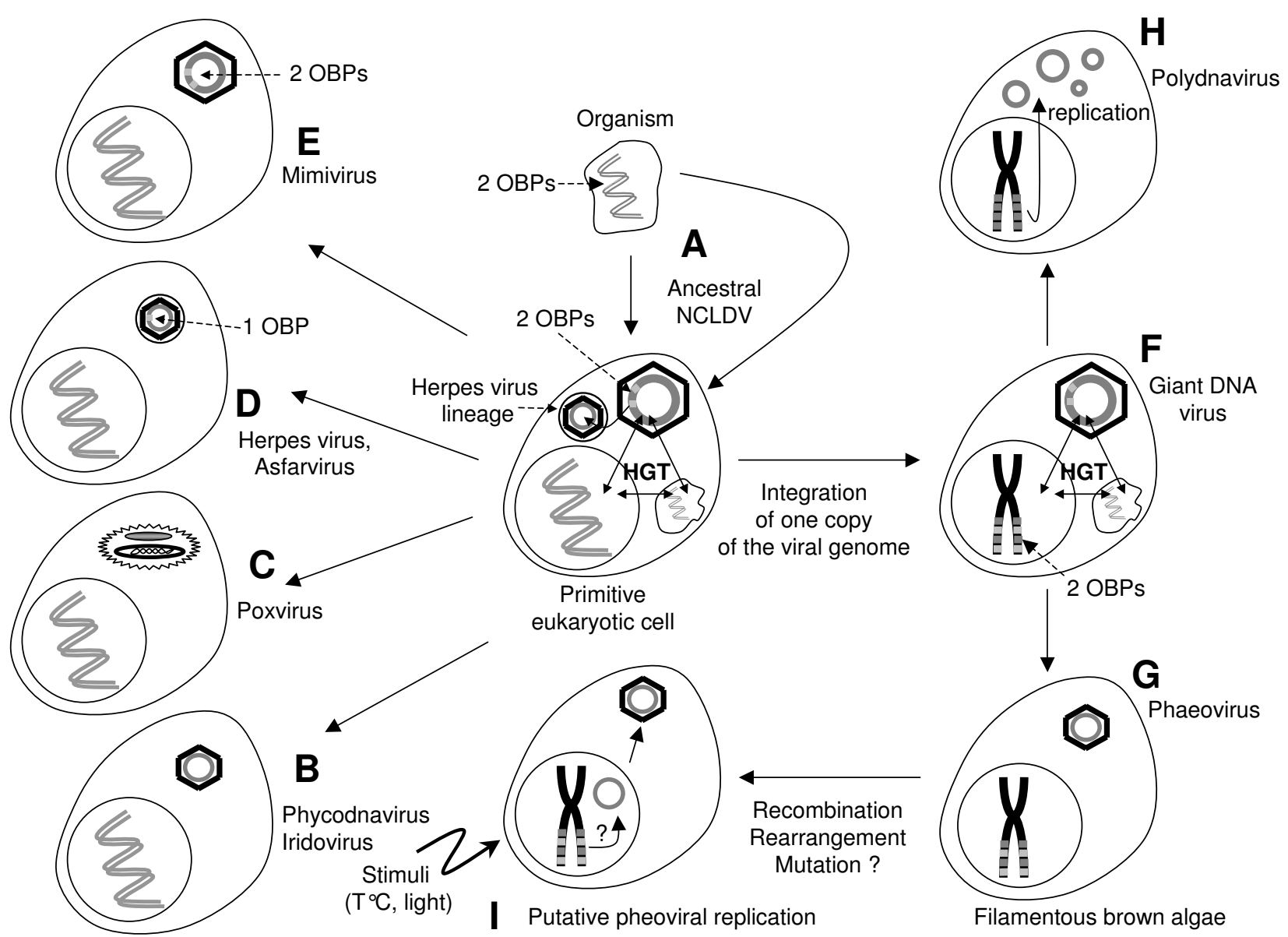

Figure 4

Putative evolution of large DNA viruses. A giant dsDNA virus or an endosymbiotic organism could be at the origin of the different classes of NCLDVs (A). This organism would have evolved mainly through genome regression as shown by the loss of the OBP ORFs (B, C, D, E). In addition, the giant microbe has probably transferred its genome to the host genome $(F)$ and evolved to give rise to the phaeoviruses $(\mathrm{G})$ and polydnaviruses $(\mathrm{H})$. It is likely that horizontal gene transfer $(\mathrm{HGT})$ occurred between the different organisms present in the primitive eukaryote (A, F). For example, the herpesvirus OBP might have been acquired from the NCLDV ancestor. In the case of the phaeoviruses, the viral integrated fragments could serve as templates for the production of new virions through rearrangement, recombination and mutation (I). 
Knowing that the OBP genes are either present or absent in the extant NCLDVs, the presence of intact and disrupted genes coding for the two different mimiviral-like OBPs genes allows us to propose the following scenario for the evolution of the different classes of NCLDV (Fig. 4 ). The different NCLDVs evolved principally through genome reduction either of a big virus or of another organism, one that had at least two OBP genes (Fig. 4). In contrast to the phycodnaviruses, the iridoviruses and poxviruses, all of which have lost both OBP genes, the asfarviruses have lost one gene each; the mimivirus, on the other hand, has conserved both genes (Fig. 4B, C, D, E). Another class of viruses, herpes viruses, might also be derived from the ancestral NCLDV because they possess one OBP and the herpes viral primase probably derived from a NCLDV primase [31]. The herpes viruses would have lost one OBP gene during the evolution (Fig. 4D). However, investigations of the structure of the capsid protein of NCLDVs and herpes viruses indicate that these viral lineages probably originated independently [33]. The herpes viruses might have therefore acquired the primase and OBP genes from a member of the NCLDV family or the NCLDV ancestor (Fig. 4A) [31,12].

In addition, the genome of the ancestral NCLDV was probably integrated into the genome of a primitive eukaryotic cell that evolved to give rise to the filamentous brown algae. During its evolution, the integrated viral genome was presumably mutated by insertion and deletion as well as disrupted by successive integrations of transposons (Fig. 1A, B). The phaeoviruses evolved principally through genome regression, which led to the loss of both OBP genes supporting the hypothesis of genome regression [25]. However, surprisingly, Ectocarpus algae have retained the intact OPB gene, regardless of its usefulness for algae or viruses. The product of the OBP gene is therefore probably necessary for the replication of the viral DNA. In fact, the OBP gene seems to be present only in Ectocarpus algae that are capable of producing viral particles and to be absent in algae in which the virus is latent (not shown).

Analysis of several NCLDVs revealed the presence of genes evolutionary related to bacterial, archaeal and eukaryotic genes [9,34]. One hypothesis suggests that horizontal gene transfer (HGT) occurred among the NCLDV ancestor, the host and endosymbionts living in the cell (Fig. 4) [13]. However, it turns out that HGT is not sufficient to account for the mosaic structure and the huge size of certain viral genomes. For example, HGT was shown to participate only somewhat in the formation of the huge genome of the mimivirus, reinforcing the idea that the ancestral NCLDV was a microbe with a large genome [14].
Another class of viruses, the polydnaviruses, could have evolved from the primitive cell that contained the ancestral NCLDV genome, given the similarities with the phaeoviruses. The polydnaviridae are a family of mutualistic dsDNA viruses associated with parasitoid wasps that parasitize other insects [35]. The genome of the polydnaviruses is present in two forms, as small DNA fragments within the genomes of wasps and as circular extra-chromosomal segments (Fig. 4H). As in EsV, the replication takes place exclusively in specialized regions of the wasp, the ovaries. The viral integrated segments are replicated, leading to the formation of the circular segments which are then injected into the prey along with the eggs. Proteins issued from the viral genes are responsible for suppressing the host's immune system and allowing the wasp's progeny to develop. In addition, although some integrated fragments are not present as circular segments after the replication, some products translated from these fragments are necessary to achieve the replication of the circular segments [36]. As mentioned above, the product of the OBP gene of region $\mathrm{C}$ might also be necessary for the EsV-1 genome to replicate itself. As in EsV, the transmission of the integrated segments follows Mendelian rules [37].

Even though polydnaviruses do not have any gene in common with phaeoviruses, the genome shares several characteristics with the phaeoviral genome, such as many genes that code for proteins with ankyrin domains. Furthermore, the genome of polydnavirus possesses remnants of transposon and retrovirus-like elements, such as the viral integrated fragments $[38,37]$. A possible symbiosis has also been mentioned for Ectocarpus and EsV, in part because the growth of Ectocarpus has been shown to be unaffected by the presence of the virus [39]. Moreover, some protein products coded by the viral genome might confer some advantages on the algae: thaumatin, for example, is a pathogen-related protein involved in plant defenses [23].

\section{A new system for integration, recombination and mutation?}

The possible homology with polydnaviruses lets us suppose that EsV also shares a similar replication system. We propose that the EsV-1 genome originates from these viral integrated sequences by means of an original recombination and rearrangement system that is triggered by environmental stimuli (Fig. 4I). Several facts support this hypothesis. First, the brown alga Feldmannia sp. is able to produce viruses having genomes with two different sizes and two variants of each, depending on the temperature at which the algae are cultivated [40]. Similarly, Feldmannia irregularis algae can produce viruses possessing numerous genomes varying from a few $\mathrm{kb}$ to $180 \mathrm{~kb}$ [25]. In the latter case, the composition of the viral genomes and the 
identity of the genes sometimes differ greatly but the order of the genes remains the same. It seems unlikely that the host genome contains one copy of each viral genome. Thus, a system may exist which produces several different viral genomes using one or a few copies as template and integrated in the algal genome.

Second, the EsV-1 and FirrV-1 genomes encode a large putative integrase/ ecombinase for which no counterpart exists in current protein databases. Only the Tyr-recombinase domain at the carboxy terminus of this enzyme is similar to phage integrases (Fig. 2). Therefore, this enzyme might be involved in the integration and/or recombination of the integrated viral fragments (Fig. 4). Moreover, the presence of two tandem copies of this enzyme accompanied by an ORF encoding a transposase and relics of another one strengthens the assumption that this enzyme is also involved in transposition.

However, the discrepancy between the integrated viral sequences and EsV-1 DNA raises questions. Such a discrepancy could be explained by the intervention of a mechanism that would edit the DNA sequences by rearrangement, recombination and mutation, leading to the formation of several different genomes. For instance, the viral recombination system could resemble the systems responsible for the diversity of the immune receptor genes [41].

The difference observed in the DNA sequence could result from one of two other factors. (i) Errors caused by the DNA polymerase during the synthesis of new viral DNA [42]; or (ii) the reparation of the viral DNA during or after replication as in E. coli. In the bacterium, the integrity of the bacterial DNA is restored after damage when it is single-stranded [43]. This could explain the presence of single-stranded DNA regions in the EsV-1 genome [24]

It can also be argued that these integrated fragments are ancient viral sequences that are degenerating, and the EsV1 genome is present as an extra chromosome. However, no episomal structures were observed in the reproductive cells [19]. If this turns out to be the case, it would be interesting to know whether the viral integrated fragments are replicated along with the EsV-1 genome or genetic exchange occurs between the viral genome and its integrated replica.

\section{Conclusion}

The huge genome of certain NCLDVs is believed to be mainly due to HGT from the different hosts they might have infected during their evolution and to gene duplication. However, such an explanation is not sufficient to account, for example, for the enormous genome of the mimivirus. Here, we show that the genome of a multicel- lular eukaryote has acquired genes from a giant DNA virus or a unicellular organism probably as big as a mimivirus but nevertheless more similar to EsV-1 at a DNA level. A comparison with the EsV-1 and other NCLDV genomes indicates that the ancestor probably lost genes during evolution, thus corroborating the genome accretion theory. Consequently, the virus should be seen not only as a gene robber but also as a major actor in shaping the genome of brown algae; it may act to shuffle genes between species. We know that EsV-1 can infect other, related brown algae [17]. Moreover, building on former results, we propose that phaeoviruses have probably developed an original replication system. Further studies will be necessary to confirm this model.

\section{Methods \\ Alga and virus cultures}

NZVicZ14 is an infected sporophyte producing EsV-1 particles as well as zoospores depending on the cultivation conditions of the algae. The cultivation of algae as well as the isolation and purification of viruses have been previously described (Lanka et al. 1993; Kapp et al. 1997).

\section{DNA extraction and purification}

The purification of viral DNA has been previously described (Lanka et al. 1993).

Total algal DNA was isolated from $1 \mathrm{~g}$ wet filaments. The algal filaments were ground to powder. The powdered filaments were mixed in $10 \mathrm{ml}$ extraction buffer $(0.1 \mathrm{M}$ Tris, $0.7 \mathrm{M} \mathrm{NaCl}, 0.1 \mathrm{M}$ EDTA, pH 8, $2 \%$ (w/v) CTAB, $0.1 \%$ SDS, $3.5 \mathrm{mM}$ DETC, $1 \% \beta$-mercaptoethanol, $3 \%(\mathrm{w} / \mathrm{v})$ PVPP) and shaken at room temperature for 1 hour. One volume (vol) of chloroform was then added to the cell lysate and centrifuged $10 \mathrm{~min}$ at 3,000 g. After centrifugation, $0.2 \mu \mathrm{g} / \mu \mathrm{l}$ RNAse A was added to the supernatant and incubated on ice for $30 \mathrm{~min}$. The supernatant was extracted twice with $1 \mathrm{vol}$ phenol/chloroform and 3 times with $1 \mathrm{vol}$ chloroform. The DNA in the supernatant was precipitated in the presence of $0.7 \mathrm{vol}$ of isopranol. The precipitated DNA was pelleted by centrifugation, dried and resuspended in $300 \mu \mathrm{l}$ of $10 \mathrm{mM}$ Tris, pH8.5.

\section{Genomic library}

Standard methods for performing restriction digests, ligation reactions and plasmid isolations were used. A cosmid library was constructed with $50 \mu \mathrm{g}$ algal DNA using the pWEB cosmid cloning Kit (Epigene) according to the manufacturer's instructions.

\section{Screening}

The library was screened by colony hybridization [44]. The algal genomic library was pre-screened using a probe that consisted of EsV-1 DNA, which was partially digested with Sau3A. Positive clones were subjected to a second 
screening with the probes $\mathrm{A}$ and $\mathrm{A}^{\prime}$ corresponding to the terminal regions ITRA and ITRA'. All the probes were labelled with ${ }^{32} \mathrm{P}$ dCTP using a NEBlot Kit (New England Biolab). After hybridization and washing, the filters were exposed to film (Kodak XAR) for 1 to three days. Positive clones were picked and plasmid DNA was extracted and purified for further analyses.

Probes A and A' were prepared by PCR using the following primers: probe A, A5, CCGCCTTCCCACCCACATTCA and A6, GTCCAACCCATCCTCTCG; probe A', A7, TGTGGGCGAGGATGCTGTCTGAAT and A8, GTGTCGAGGCGCGTATGTTGAAAT. Thermocycling conditions were 30 cycles of denaturation at $94^{\circ} \mathrm{C}$ for $1 \mathrm{~min}$, annealing at $60^{\circ} \mathrm{C}$ for $1 \mathrm{~min}$, and extension at $72^{\circ} \mathrm{C}$ for $1 \mathrm{~min}$, followed by a final 5 -min extension at $72^{\circ} \mathrm{C}$.

\section{Sequencing}

A shotgun library of each positive cosmid and plasmid DNA was constructed. DNA was partially digested with Sau3A. The 1-5 kb DNA fragments were gel purified, ligated into the BamHI site of CIP-treated plasmid pUC19 (Fermentas), and transformed into E. coli Max Efficiency Stbl2 (Invitrogen). DNA sequencing was carried out with the big dye kit (Perkin-Elmer) and sequences were analyzed on an ABI 377 sequencer. The shotgun sequences were assembled with the SeqManII Lasergene Software (DNASTAR Inc.) until a coverage of 10 was reached. Gaps between DNA segments were closed using PCR.

\section{Analysis of sequence data}

The open reading frames (ORFs) were identified with the laser-gene biocomputing software package (DNASTAR Inc.). Homology searches were carried out with the blast program [45]. Protein motifs were searched against the SMART [46] and Pfam [47] databases. Sequence alignments were performed with the Megalign program (DNASTAR Inc.).

\section{Nucleotide sequence accession numbers}

The DNA nucleotide sequences of the contigs have been deposited in GenBank under the following accession numbers: EU254745, EU254746 and EU254747

\section{Authors' contributions}

ND conceived of the study, carried out the molecular genetic studies, provided the biological interpretation of the results, and finalized the manuscript. WB drafted the manuscript. All authors read and approved the final manuscript.

\section{Acknowledgements}

We thank D. Schnabelrauch for DNA sequencing, V. Roman for technical help and Dr. M. J. Cock for his comments. This work was supported in part from Marine Genomics Europe, through framework programme FP6 of the European Commission.

\section{References}

I. Villarreal LP, DeFilippis VR: A hypothesis for DNA viruses as the origin of eukaryotic replication proteins. J Virol 2000, 74(I 5):7079-7084.

2. Bell PJ: Viral eukaryogenesis: was the ancestor of the nucleus a complex DNA virus? J Mol Evol 200 I, 53(3):25I-256.

3. Bell PJ: Sex and the eukaryotic cell cycle is consistent with a viral ancestry for the eukaryotic nucleus. J Theor Biol 2006.

4. Takemura M: Poxviruses and the origin of the eukaryotic nucleus. J Mol Evol 200I, 52(5):419-425.

5. Filee J, Forterre P, Sen-Lin T, Laurent J: Evolution of DNA polymerase families: evidences for multiple gene exchange between cellular and viral proteins. I Mol Evol 2002, 54(6):763-773.

6. Claverie JM: Viruses take center stage in cellular evolution. Genome Biol 2006, 7(6): I I0.

7. Forterre $P$ : The origin of viruses and their possible roles in major evolutionary transitions. Virus Research 2006, I I 7(I):5-16.

8. Van Etten JL, Graves MV, Muller DG, Boland W, Delaroque N: Phycodnaviridae--large DNA algal viruses. Arch Virol 2002, |47(8): |479- I 5 |6.

9. Raoult D, Audic S, Robert C, Abergel C, Renesto P, Ogata H, La Scola $B$, Suzan M, Claverie JM: The I.2-megabase genome sequence of mimivirus. Science 2004, 306(5700): I344- I 350.

10. Wilson WH, Schroeder DC, Allen MJ, Holden MT, Parkhill J, Barrell BG, Churcher C, Hamlin N, Mungall K, Norbertczak H, Quail MA, Price C, Rabbinowitsch E, Walker D, Craigon M, Roy D, Ghazal P: Complete genome sequence and lytic phase transcription profile of a Coccolithovirus. Science 2005, 309(5737): 1090-1092.

II. lyer LM, Aravind L, Koonin EV: Common origin of four diverse families of large eukaryotic DNA viruses. J Virol 200I, 75(23): I I 720-I I 734.

12. lyer LM, Balaji S, Koonin EV, Aravind L: Evolutionary genomics of nucleo-cytoplasmic large DNA viruses. Virus Res 2006, I I 7( I): I56-184.

13. Koonin EV, Senkevich TG, Dolja VV: The ancient Virus World and evolution of cells. Biol Direct 2006, I(29):29.

14. Moreira D, López-García P: Comment on "The I.2-megabase genome sequence of Mimivirus". Science 2005, 308(5725): III4.

15. Suhre K, Audic S, Claverie JM: Mimivirus gene promoters exhibit an unprecedented conservation among all eukaryotes. Proceedings of the National Academy of Sciences of the United States of America 2005, I 02(4I): |4689-|4693.

16. Suhre K: Gene and genome duplication in Acanthamoeba polyphaga Mimivirus. Journal of Virology 2005, 79(22): I4095-|4101.

17. Muller DG, Kapp M, Knippers R: Viruses in marine brown algae. Adv Virus Res 1998, 50:49-67.

18. Brautigam M, Klein M, Knippers R, Muller DG: Inheritance and meiotic elimination of a virus genome in the host ectocarpus siliculosus (phaeophyceae). Journal of Phycology 1995, 3 I (5):823-827.

19. Delaroque N, Maier I, Knippers R, Muller DG: Persistent virus integration into the genome of its algal host, Ectocarpus siliculosus (Phaeophyceae). Journal of General Virology 1999, 80(Pt 6): I367- I370.

20. Mueller DG: Mendelian segregation of a virus genome during host meiosis in the marine brown alga Ectocarpus siliculosus. J Plant Physiol 1991, 137:739-743.

21. Müller DGK H. Stache, B. Lanka, S.: A virus infection in the marine brown alga Ectocarpus siliculosus (Phaeophyceae). Botanica Acta 1990, I03:72-82.

22. Lanka ST, Klein M, Ramsperger U, Muller DG, Knippers R: Genome structure of a virus infecting the marine brown alga Ectocarpus siliculosus. Virology 1993, I93(2):802-8I I.

23. Delaroque N, Muller DG, Bothe G, Pohl T, Knippers R, Boland W: The complete DNA sequence of the Ectocarpus siliculosus virus EsV-I genome. Virology 200I, 287(I): I I2-I32.

24. Klein M, Lanka S, Muller D, Knippers R: Single-stranded regions in the genome of the Ectocarpus siliculosus virus. Virology 1994, 202(2): $1076-1078$. 
25. Delaroque N, Boland W, Muller DG, Knippers R: Comparisons of two large phaeoviral genomes and evolutionary implications. J Mol Evol 2003, 57(6):613-622.

26. Muller DG, Sengco M, Wolf S, Brautigam M, Schmid CE, Kapp M, Knippers R: Comparison of two DNA viruses infecting the marine brown algae Ectocarpus siliculosus and E. fasciculatus. J Gen Virol 1996, 77 ( Pt 9):2329-2333.

27. Deneke J, Burgin AB, Wilson SL, Chaconas G: Catalytic residues of the telomere resolvase ResT: a pattern similar to, but distinct from, tyrosine recombinases and type IB topoisomerases. J Biol Chem 2004, 279(5 I):53699-706. Epub 2004 Oct 6..

28. Nunes-Duby SE, Kwon HJ, Tirumalai RS, Ellenberger T, Landy A: Similarities and differences among 105 members of the Int family of site-specific recombinases. Nucleic Acids Res 1998, 26(2):391-406.

29. O'Day DH, Suhre K, Myre MA, Chatterjee-Chakraborty M, Chavez SE: Isolation, characterization, and bioinformatic analysis of calmodulin-binding protein cmbB reveals a novel tandem IP22 repeat common to many Dictyostelium and Mimivirus proteins. Biochem Biophys Res Commun 2006, 346(3):879-888.

30. Lehman IR, Boehmer PE: Replication of herpes simplex virus DNA. J Biol Chem 1999, 274(40):28059-28062.

31. Iyer LM, Koonin EV, Leipe DD, Aravind L: Origin and evolution of the archaeo-eukaryotic primase superfamily and related palm-domain proteins: structural insights and new members. Nucleic Acids Research 2005, 33( I 2):3875-3896.

32. Lee AM, Ivey RG, Meints RH: Repetitive DNA insertion in a protein kinase ORF of a latent FSV (Feldmannia sp. virus) genome. Virology 1998, 248(I):35-45.

33. Bamford DH, Grimes JM, Stuart DI: What does structure tell us about virus evolution? Curr Opin Struct Biol 2005, I 5(6):655-63. Epub 2005 Nov 3..

34. Dunigan DD, Fitzgerald LA, Van Etten JL: Phycodnaviruses: A peek at genetic diversity. Virus Research 2006, I I 7(I): I I9-132.

35. Kroemer JA, Webb BA: Polydnavirus genes and genomes: emerging gene families and new insights into polydnavirus replication. Annu Rev Entomol 2004, 49:43I-456.

36. Deng $L$, Stoltz DB, Webb BA: A gene encoding a polydnavirus structural polypeptide is not encapsidated. Virology 2000, 269(2):440-450.

37. Webb BA, Strand MR, Dickey SE, Beck MH, Hilgarth RS, Barney WE, Kadash K, Kroemer JA, Lindstrom KG, Rattanadechakul W, Shelby KS, Thoetkiattikul H, Turnbull MW, Witherell RA: Polydnavirus genomes reflect their dual roles as mutualists and pathogens. Virology 2006, 347(I): I60-I74.

38. Espagne E, Dupuy C, Huguet E, Cattolico L, Provost B, Martins N, Poirie M, Periquet G, Drezen JM: Genome sequence of a polydnavirus: insights into symbiotic virus evolution. Science 2004, 306(5694):286-289.

39. Campo ED, Ramazanov Z, Garcia-Reina G, Müller DG: Photosynthetic responses and growth performance of virus-infected and noninfected Ectocarpus siliculosus. Phycologia 1997. 36(3): $186-189$.

40. Ivey RG, Henry EC, Lee AM, Klepper L, Krueger SK, Meints RH: A Feldmannia algal virus has two genome size-classes. Virology 1996, 220(2):267-273.

4I. Litman GW, Cannon JP, Dishaw LJ: Reconstructing immune phylogeny: new perspectives. Nat Rev Immunol 2005, 5( I I ):866-879.

42. Speyer JF: Mutagenic DNA polymerase. Biochem Biophys Res Commun 1965, 2 I (I):6-8.

43. Viswanathan M, Lovett ST: Single-strand DNA-specific exonucleases in Escherichia coli. Roles in repair and mutation avoidance. Genetics 1998, I49(I):7-16.

44. Sambrook J, Fritsch EF, Maniatis T: Molecular Cloning - A Laboratory Manual. 2nd edition. New York, Cold Spring Harbor Press, Cold Spring Harbor; 1989.

45. Altschul SF, Gish W, Miller W, Myers EW, Lipman DJ: Basic loca alignment search tool. J Mol Biol 1990, 2 I 5(3):403-4I0.

46. Schultz J, Milpetz F, Bork P, Ponting CP: SMART, a simple modular architecture research tool: identification of signaling domains. Proc Natl Acad Sci U S A 1998, 95(I I):5857-5864.

47. Finn RD, Mistry J, Schuster-Bockler B, Griffiths-Jones S, Hollich V, Lassmann T, Moxon S, Marshall M, Khanna A, Durbin R, Eddy SR, Sonnhammer EL, Bateman A: Pfam: clans, web tools and services. Nucleic Acids Res 2006, 34(Database issue):D247-5I.
Publish with Biomed Central and every scientist can read your work free of charge

"BioMed Central will be the most significant development for disseminating the results of biomedical research in our lifetime. "

Sir Paul Nurse, Cancer Research UK

Your research papers will be:

- available free of charge to the entire biomedical community

- peer reviewed and published immediately upon acceptance

- cited in PubMed and archived on PubMed Central

- yours - you keep the copyright 